\title{
Novel Intraoral Negative Airway Pressure in Drug-Induced Sleep Endoscopy with Target-Controlled Infusion [Corrigendum]
}

Kuo YH, Liu TJ, Chiu FH, et al. Nat Sci Sleep. 2021;13:2087-2099.

The authors have advised that the funding statement on page 2098 is incorrect. The text "This study was supported by a grant from Shin Kong Wu- Ho-Su memorial Hospital (2018SKHADR018)" should read "This study was supported by a grant from Shin Kong Wu-Ho-Su memorial Hospital (2019SKHADR027)".

The authors apologize for this error.

\section{Publish your work in this journal}

Nature and Science of Sleep is an international, peer-reviewed, open access journal covering all aspects of sleep science and sleep medicine, including the neurophysiology and functions of sleep, the genetics of sleep, sleep and society, biological rhythms, dreaming, sleep disorders and therapy, and strategies to optimize healthy sleep. The manuscript management system is completely online and includes a very quick and fair peer-review system, which is all easy to use. Visit http://www.dovepress.com/testimonials.php to read real quotes from published authors. 